\title{
On The Use of Transportation Techniques to Determine the Cost of Transporting Commodity
}

\author{
Ajibade, A.D ${ }^{(1) ;}$ Babarinde, S.N ${ }^{(2)}$ \\ ${ }^{I}$ Department of Mathematics \& Statistics, The Polytechnic Ibadan, Nigeria \\ ${ }^{2}$ Department of Business Administration, The Polytechnic Ibadan, Nigeria
}

\begin{abstract}
This paper aims at identifying an effective and appropriate method of calculating the cost of transporting goods from several supply centers to several demand centers out of many available methods. Transportation algorithms of North-West corner method (NWCM), Least Cost Method (LCM), Vogel's Approximation Method (VAM) and Optimality Test were carried out to estimate the cost of transporting produced newspaper from production center to ware-houses using Statistical software called TORA. The results revealed that: $N W C M=36,689,050.00, L C M=55,250,034.00, V A M=29,097,700.00$ and Optimal solution = 19,566,332.00. It was discovered that Vogel's Approximation method gives the transportation cost that closer to optimal solution. Also, the study revealed that a production center should be created at northern part of Nigeria to replace the dummy supply center used in the analysis, so as to make production capacity equal to requirement.
\end{abstract}

Key Words: algorithm, transportation, optimal solution, degeneracy, dummy.

\section{Introduction}

In the theory of production, what to produce and for whom to produce are critical problems encounter by many producers in developing countries such as Nigeria. After solving the stated problems, cost of production is another economic problem contributing to the price of a produced commodity. This is revealing from economic perspective that says price of commodity greatly rely on the cost of producing such commodity. One of the confounding determinants of production cost is cost of transporting manufactured goods from supply centers to demand centers. This paper attempted at providing an appropriate method of calculating the cost of transporting a homogeneous product from manufacturing centers to consumption centers so as to guide the company in minimizing the cost of moving her products to demand areas.

The study of transportation problem helps to identify optimal transportation routes along with units of commodity to be shipped in order to minimize total transportation cost (J.K Sharma 2009). Transportation problem arises where there exist the need to move a set of items from the number of different sources (with each source having certain capacity) to a number of destination (with each destination requiring a certain capacity). One of the models that explained the study of transportation problem is Linear Programming (LP), but important application of this linear programming is in the area of physical distribution of goods and services after production to the consumption centers (Richard Bronson et al. 1997). At times, transportation problem can be expressed in terms of LP model which can be solved by the simplex method or other methods of solving a system of linear equations. There are various types of transportation models and the simplest of them was first presented by F.L Hitchcock (1941) and developed by T.C. Koopmans (1949) and G.B. Dantzing (1951). Later, several models and methods have been subsequently developed.

Transportation problem solution attempts to minimize total transportation cost and at the same time satisfy the destination requirement given the transportation cost per unit. The transportation problem is a form of linear programming problem, therefore, is an allocation problem for which a special technique or method of providing solution to a problem has been developed. However, the transportation algorithm is specially design to provide optimum solution to problems arise as a result of transporting product or allocation of services or delivery from several origins to various destinations, where the total requirements at each destination are known quantities, thus, deciding along which routes are the best they should be dispatched.

In business, sources could be factories and destinations could be warehouses or customer's shops. It should be noted that transportation problems are usually minimization problems.

The limitation of linear programming model is involvement of a large number of variables and constraints that may takes a long time to solve manually. This problem is solved by the researchers, through the help of statistical software called TORA.

\section{Some Useful Concepts Used}

i. Unbalanced Transportation Problem: A transportation problem is said to be unbalanced when the total demand is not equal to the total supply. In this situation, there will be need to create a dummy and 
this depends on the excess or shortage between the demand and the supply. That is there will be need to create dummy demand if supply is greater than demand or dummy supply if the demand is greater than supply with zero cost of transportation.

ii. Balanced Transportation Problem: A transportation problem is said to be balanced when the total demand is equal to the total supply. That is $\sum_{i=1}^{m} a_{i}=\sum_{j=11}^{n} b_{i}$

In this paper, we have unbalanced transportation problem, because the total demand is greater than total supply. However, dummy supply with zero cost of transportation was created to make total supply equal total demand and transportation algorithm of North-West Corner Method, Least Cost Method, Vogel's Approximation Method as well as Optimization test were adopted to calculate the cost of transporting a homogenous commodity (Newspaper) from supply centers to demand centers. Later, the result of NWCM, LCM and VAM are compared with the result of optimality test to identify the method that gives minimum value of the total cost of transporting the product under study (newspaper).

iii. Degeneracy: A basic feasible solution of any standard transportation problem with m sources of supply and $\mathrm{n}$ demand destination require that allocation be made in (column + row -1 ). Degeneracy of a solution occurs when the resources of a row are exhausted and the requirements of a column are satisfied by a single allocation. So, if this happens, it is important to calculate the shadow cost and the only solution is to treat one of the unoccupied cells as if it was occupied cell or as if it had a zero allocation.

iv. Optimality: In transportation problem, an optimal solution is a solution obtained and there is no other set of transportation routes (allocations) that will further reduce the total transportation cost.

\section{Material and Methods}

Data used for this research was provided by African Newspapers of Nigerian Plc (Nigerian Tribune). The data covered ten years of supplying Newspapers from 3 supply centers or plants (Ibadan, Abuja and PortHarcourt) to 12 demand centers (Abeokuta, Ado-Ekiti, Ilorin, Osogbo, Kano, Sokoto, Jos, Warri, Benin, Owerri, Enugu and Makurdi) between 2001 and 2010.

A transportation problem involves $M$ sources, each of which has available $a_{i}(i=1,2, \ldots . m)$ units of a homogeneous product and $n$ destination, each of which requires $b_{j}(j=1,2, \ldots \ldots n)$ units of the product (Newspaper). The numbers $a_{j}$ and $b_{j}$ are positive integers. The cost $C_{i j}$ of transporting one unit of product from the $\mathrm{i}^{\text {th }}$ destination is given for each $\mathrm{i}$ and $\mathrm{j}$.

It is assumed that total supply and total demand are equal that is

$$
\sum_{i=1}^{m} a_{i}=\sum_{j=11}^{n} b_{i}
$$

The above equation is guaranteed by creating either a fictitious destination with a demand equal to the surplus, if total demand is less than the total supply, or a fictitious source with a supply equal to the shortage if total demand exceeds total supply. problem is

If $\mathrm{x}_{\mathrm{ij}}$ represent the number of units to be shipped from sources $\mathrm{i}$ to $\mathrm{j}$, mathematical model for the

$$
\begin{gathered}
\text { minz }=\sum_{\substack{\mathrm{i} \\
\text { Subject to }}}^{\mathrm{m}} \sum_{\mathrm{j}}^{\mathrm{n}} \mathrm{C}_{\mathrm{ij}} \mathrm{X}_{\mathrm{ij}} \\
\sum_{\mathrm{j}}^{\mathrm{n}} \mathrm{X}_{\mathrm{ij}} \leq \mathrm{a}_{\mathrm{i}} \text { for all } i \\
\sum_{\mathrm{i}}^{\mathrm{m}} \mathrm{X}_{\mathrm{ij}} \geq \mathrm{b}_{\mathrm{j}} \quad \text { for all } j \\
\mathrm{X}_{\mathrm{ij}} \geq 0, \quad \Sigma a_{\mathrm{i}} \geq \Sigma \mathrm{b}_{\mathrm{j}} \quad \mathrm{C}_{\mathrm{ij}} \geq \mathbf{0}
\end{gathered}
$$


Layout of transportation problem:

\begin{tabular}{|l|l|l|l|l|l|}
\hline & $\mathrm{D}_{1}$ & $\mathrm{D}_{2}$ & $\cdots$ & $\mathrm{D}_{\mathrm{n}}$ & Supply \\
\hline $\mathrm{S}_{1}$ & $\mathrm{C}_{11}$ & $\mathrm{C}_{12}$ & $\cdots$ & $\mathrm{C}_{1 \mathrm{n}}$ & $\mathrm{a}_{1}$ \\
& $\mathrm{X}_{11}$ & $\mathrm{X}_{12}$ & $\cdots$ & $\mathrm{X}_{1 \mathrm{n}}$ & \\
\hline $\mathrm{S}_{2}$ & $\mathrm{C}_{21}$ & $\mathrm{C}_{22}$ & $\cdots$ & $\mathrm{C}_{2 \mathrm{n}}$ & $\mathrm{a}_{2}$ \\
& $\mathrm{X}_{21}$ & $\mathrm{X}_{22}$ & $\cdots$ & $\mathrm{X}_{2 \mathrm{n}}$ & \\
\hline $\mathrm{S}_{3}$ & $\mathrm{C}_{31}$ & $\mathrm{C}_{32}$ & $\cdots$ & $\mathrm{C}_{3 \mathrm{n}}$ & $\mathrm{a}_{3}$ \\
& $\mathrm{X}_{31}$ & $\mathrm{X}_{32}$ & $\cdots$ & $\mathrm{X}_{3 \mathrm{n}}$ & \\
\hline$\cdot$ & $\cdot$ & $\cdot$ & $\cdots$ & $\cdot$ & $\cdot$ \\
. & $\cdot$ & $\cdot$ & $\cdots$ & $\cdot$ & $\cdot$ \\
. & $\cdot$ & $\cdot$ & $\cdots$ & $\cdot$ & $\cdot$ \\
\hline $\mathrm{S}_{\mathrm{m}}$ & $\mathrm{C}_{\mathrm{m} 1}$ & $\mathrm{C}_{\mathrm{m} 2}$ & $\cdots$ & $\mathrm{C}_{\mathrm{mn}}$ & $\mathrm{a}_{\mathrm{m}}$ \\
& $\mathrm{X}_{\mathrm{m} 1}$ & $\mathrm{X}_{\mathrm{m} 2}$ & $\cdots$ & $\mathrm{X}_{\mathrm{mn}}$ & \\
\hline Demand & $\mathrm{b}_{1}$ & $\mathrm{~b}_{2}$ & $\cdots$ & $\mathrm{b}_{\mathrm{n}}$ & $\sum_{i=1}^{m} a_{i}=\sum_{j=11}^{n} b_{i}$ \\
\hline
\end{tabular}

Table 1:

where:

$\mathrm{C}_{\mathrm{ij}}$ is the cost of transporting unit from depot $\mathrm{i}$ to destination $\mathrm{j}$.

$\mathrm{X}_{\mathrm{ij}}$ is the quantity allocated to destination $\mathrm{j}$ from depot $\mathrm{i}$.

$\mathrm{S}_{\mathrm{i}}$ is the source of depot $\mathrm{i}$

$D_{j}$ is the destination $j$

$\mathrm{a}_{\mathrm{i}}$ is the capacity of source or distribution centre $\mathrm{i}$

$b_{j}$ is the demand or requirement of destination $j$

$\sum_{i=1}^{m} a_{i}=\sum_{j=11}^{n} b_{i}$ is the total

\section{Algorithms}

The first approximation or computation system is always integral and therefore serves as optimal solution, rather than determining the approximation by a direct application of the simplex method specialized to detect the optimal solution, transportation algorithms of NWCM, LCM, and VAM are employed. To use any one of the stated algorithms, one must follow the following steps:

1. Computation of initial basic feasible solution.

2. Testing the optimality of the solution in step 1

3. Improving the solution established in step1 when it is not optimal

4. Repeating steps (2) and (3) until the optimal solution is obtained.

\section{Data presentation, analysis and interpretation of results}

The data collected from Nigerian Tribune is summarized on table 2 and the results of analyses are presented on table 3, 4, 5 and 6 :

\begin{tabular}{|c|c|c|c|c|c|}
\hline $\begin{array}{l}\text { Supply/demand } \\
\text { centers }\end{array}$ & $\begin{array}{l}\text { IBADAN } \\
\ldots\end{array}$ & $\underset{A B U J A}{A B U}$ & $\begin{array}{l}\text { PORT } \\
\text { HARCOURT } \\
\text { \# }\end{array}$ & $\begin{array}{l}\text { DUMMY } \\
\#\end{array}$ & REQUIREMNT \\
\hline Abeokuta & 9 & 38 & 45 & 0 & 867650 \\
\hline Ado & 16 & 29 & 33 & 0 & 1466217 \\
\hline Ilorin & 15 & 24 & 30 & 0 & 2878598 \\
\hline Osogbo & 10 & 32 & 37 & 0 & 2252565 \\
\hline Kano & 40 & 16 & 24 & 0 & 413468 \\
\hline Sokoto & 52 & 19 & 28 & 0 & 765150 \\
\hline Jos & 49 & 17 & 38 & 0 & 603336 \\
\hline Warri & 53 & 33 & 13 & 0 & 645788 \\
\hline Benni & 38 & 42 & 21 & 0 & 1997399 \\
\hline
\end{tabular}


On The Use of Transportation Techniques to Determine the Cost of Transporting Commodity

\begin{tabular}{|l|l|l|l|l|l|}
\hline Owerri & 44 & 37 & 12 & 0 & 1249873 \\
\hline Enugu & 52 & 39 & 17 & 0 & 1024606 \\
\hline Makurdi & 59 & 21 & 41 & 0 & 341292 \\
\hline CAPACITY & 673,000 & 530,000 & 409400 & 12893542 & 14,505942 \\
\hline
\end{tabular}

Table 2.

North - West Corner Method (NWCM)

Table:3 OBJECTIVE FUNCTION: 36,689,050.00

\begin{tabular}{|c|c|c|c|c|c|c|c|c|c|c|c|c|c|}
\hline & $\begin{array}{l}\mathrm{ABE} \\
\mathrm{OKU} \\
\mathrm{TA}\end{array}$ & $\mathrm{ADO}$ & $\begin{array}{l}\text { ILO } \\
\text { RIN }\end{array}$ & $\begin{array}{l}\text { OSO } \\
\text { GBO }\end{array}$ & $\begin{array}{l}\text { KA } \\
\text { NO }\end{array}$ & $\begin{array}{l}\text { SOK } \\
\text { OTO }\end{array}$ & JOS & $\begin{array}{l}\text { WA } \\
\text { RRI }\end{array}$ & $\begin{array}{l}\text { BENI } \\
\mathrm{N}\end{array}$ & $\begin{array}{l}\text { OWE } \\
\text { RRI }\end{array}$ & $\begin{array}{l}\text { ENI } \\
\text { UGU }\end{array}$ & $\begin{array}{l}\text { MA } \\
\text { RK } \\
\text { UR } \\
\text { DI }\end{array}$ & $\begin{array}{l}\text { SUPP } \\
\text { LY }\end{array}$ \\
\hline $\begin{array}{l}\text { IBADA } \\
\mathrm{N}\end{array}$ & $\begin{array}{l}6730 \\
00 \\
\end{array}$ & & & & & & & & & & & & $\begin{array}{l}67300 \\
0\end{array}$ \\
\hline ABUJA & $\begin{array}{l}1946 \\
50\end{array}$ & $\begin{array}{l}3353 \\
50\end{array}$ & & & & & & & & & & & $\begin{array}{l}\text { 53000 } \\
0\end{array}$ \\
\hline $\begin{array}{l}\text { PORT } \\
\text { HARC } \\
\text { OURT }\end{array}$ & & $\begin{array}{l}4094 \\
00\end{array}$ & & & & & & & & & & & $\begin{array}{l}40940 \\
0\end{array}$ \\
\hline $\begin{array}{l}\text { DUMM } \\
\text { Y }\end{array}$ & & $\begin{array}{l}7214 \\
67\end{array}$ & $\begin{array}{l}2878 \\
598\end{array}$ & $\begin{array}{l}2252 \\
565\end{array}$ & $\begin{array}{l}4134 \\
68\end{array}$ & $\begin{array}{l}7651 \\
50\end{array}$ & $\begin{array}{l}603 \\
336\end{array}$ & $\begin{array}{l}6457 \\
88\end{array}$ & $\begin{array}{l}1997 \\
399\end{array}$ & $\begin{array}{l}1249 \\
873\end{array}$ & $\begin{array}{l}1024 \\
606\end{array}$ & $\begin{array}{l}3412 \\
92\end{array}$ & $\begin{array}{l}12893 \\
542\end{array}$ \\
\hline $\begin{array}{l}\text { DEMA } \\
\text { ND }\end{array}$ & $\begin{array}{l}8676 \\
50\end{array}$ & $\begin{array}{l}1466 \\
217\end{array}$ & $\begin{array}{l}2878 \\
598\end{array}$ & $\begin{array}{l}2252 \\
565\end{array}$ & $\begin{array}{l}4134 \\
68\end{array}$ & $\begin{array}{l}7651 \\
50\end{array}$ & $\begin{array}{l}603 \\
336\end{array}$ & $\begin{array}{l}6457 \\
88\end{array}$ & $\begin{array}{l}1997 \\
399\end{array}$ & $\begin{array}{l}1249 \\
873\end{array}$ & $\begin{array}{l}1024 \\
606\end{array}$ & $\begin{array}{l}3412 \\
92\end{array}$ & \\
\hline
\end{tabular}

Table:4

Least Cost Method (LCM)

\begin{tabular}{|c|c|c|c|c|c|c|c|c|c|c|c|c|c|}
\hline & $\begin{array}{l}\text { ABE } \\
\text { OK } \\
\text { UTA }\end{array}$ & $\begin{array}{l}\mathrm{AD} \\
\mathrm{O}\end{array}$ & $\begin{array}{l}\text { ILO } \\
\text { RIN }\end{array}$ & $\begin{array}{l}\text { OS } \\
\text { OG } \\
\text { BO }\end{array}$ & $\begin{array}{l}\text { KA } \\
\text { NO }\end{array}$ & $\begin{array}{l}\text { SO } \\
\text { KO } \\
\text { TO }\end{array}$ & $\begin{array}{l}\text { JO } \\
\text { S }\end{array}$ & $\begin{array}{l}\text { WA } \\
\text { RRI }\end{array}$ & $\begin{array}{l}\text { BEN } \\
\text { IN }\end{array}$ & $\begin{array}{l}\text { OW } \\
\text { ERR } \\
\text { I }\end{array}$ & $\begin{array}{l}\text { ENI } \\
\text { UG } \\
\text { U }\end{array}$ & $\begin{array}{l}\text { MA } \\
\text { RK } \\
\text { UR } \\
\text { DI }\end{array}$ & $\begin{array}{l}\text { SUPP } \\
\text { LY }\end{array}$ \\
\hline $\begin{array}{l}\text { IBAD } \\
\text { AN }\end{array}$ & & & & & & & & & & & $\begin{array}{l}\text { 6730 } \\
00\end{array}$ & & $\begin{array}{l}67300 \\
0\end{array}$ \\
\hline $\begin{array}{l}\text { ABUJ } \\
\text { A }\end{array}$ & & & & & & & & & & & $\begin{array}{l}1887 \\
08\end{array}$ & $\begin{array}{l}341 \\
292\end{array}$ & $\begin{array}{l}53000 \\
0\end{array}$ \\
\hline $\begin{array}{l}\text { PORT } \\
\text { HARC } \\
\text { OURT }\end{array}$ & & & & & & & & & & $\begin{array}{l}2465 \\
02\end{array}$ & $\begin{array}{l}1628 \\
98\end{array}$ & & $\begin{array}{l}40940 \\
0\end{array}$ \\
\hline $\begin{array}{l}\text { DUM } \\
\text { MY }\end{array}$ & $\begin{array}{l}8676 \\
50\end{array}$ & $\begin{array}{l}1466 \\
217\end{array}$ & $\begin{array}{l}2878 \\
598\end{array}$ & $\begin{array}{l}225 \\
256 \\
5\end{array}$ & $\begin{array}{l}413 \\
468\end{array}$ & $\begin{array}{l}765 \\
150\end{array}$ & $\begin{array}{l}603 \\
336\end{array}$ & $\begin{array}{l}645 \\
788\end{array}$ & $\begin{array}{l}1997 \\
399\end{array}$ & $\begin{array}{l}1003 \\
371\end{array}$ & & & $\begin{array}{l}12893 \\
542\end{array}$ \\
\hline $\begin{array}{l}\text { DEMA } \\
\text { ND }\end{array}$ & $\begin{array}{l}8676 \\
50\end{array}$ & $\begin{array}{l}1466 \\
217\end{array}$ & $\begin{array}{l}2878 \\
598\end{array}$ & $\begin{array}{l}225 \\
256 \\
5\end{array}$ & $\begin{array}{l}413 \\
468\end{array}$ & $\begin{array}{l}765 \\
150\end{array}$ & $\begin{array}{l}603 \\
336\end{array}$ & $\begin{array}{l}645 \\
788\end{array}$ & $\begin{array}{l}1997 \\
3999\end{array}$ & $\begin{array}{l}1249 \\
873\end{array}$ & $\begin{array}{l}1024 \\
606\end{array}$ & $\begin{array}{l}341 \\
292\end{array}$ & \\
\hline
\end{tabular}

Vogel's Approximation Method (VAM)

Table:5

OBJECTIVE FUNCTION: 29,097,700.00

\begin{tabular}{|l|l|l|l|l|l|l|l|l|l|l|l|l|l|}
\hline & $\begin{array}{l}\text { ABE } \\
\text { OKU } \\
\text { TA }\end{array}$ & ADO & $\begin{array}{l}\text { ILO } \\
\text { RIN }\end{array}$ & $\begin{array}{l}\text { OSO } \\
\text { GBO }\end{array}$ & $\begin{array}{l}\text { KA } \\
\text { NO }\end{array}$ & $\begin{array}{l}\text { SOK } \\
\text { OTO }\end{array}$ & JOS & $\begin{array}{l}\text { WA } \\
\text { RRI }\end{array}$ & $\begin{array}{l}\text { BENI } \\
\text { N }\end{array}$ & $\begin{array}{l}\text { OW } \\
\text { ERR } \\
\text { I }\end{array}$ & $\begin{array}{l}\text { ENI } \\
\text { UG } \\
\text { U }\end{array}$ & $\begin{array}{l}\text { MA } \\
\text { RK } \\
\text { UR } \\
\text { DI }\end{array}$ & $\begin{array}{l}\text { SUPP } \\
\text { LY }\end{array}$ \\
\hline $\begin{array}{l}\text { IBADA } \\
\text { N }\end{array}$ & $\begin{array}{l}\mathbf{6 7 3 0} \\
\mathbf{0 0}\end{array}$ & & & & & & & & & & & & $\begin{array}{l}\mathbf{6 7 3 0 0} \\
\mathbf{0}\end{array}$ \\
\hline ABUJA & $\begin{array}{l}\mathbf{1 9 4 6} \\
\mathbf{5 0}\end{array}$ & & & $\begin{array}{l}\mathbf{3 3 5 3} \\
\mathbf{5 0}\end{array}$ & & & & & & & & & $\mathbf{5 3 0 0 0}$ \\
$\mathbf{0}$
\end{tabular}




\begin{tabular}{|l|l|l|l|l|}
\hline \multicolumn{9}{|l}{ Optimal Solution } \\
\hline From & To & Amt. Shipped & Obj. Coeff. & Obj. Contrib. \\
\hline S1: IBADAN & $\begin{array}{l}\text { D1: } \\
\text { ABEOKUTA }\end{array}$ & 673000 & 9.00 & 6057000.00 \\
\hline S2: ABUJA & D5: KANO & 413468 & 16.00 & 6615488.00 \\
\hline S2: ABUJA & D7: JOS & 116532 & 17.00 & 1981044.00 \\
\hline $\begin{array}{l}\text { S3: } \\
\text { PORTHARCOURT }\end{array}$ & D10: OWERRI & 409400 & 12.00 & 4912800.00 \\
\hline S4: DUMMY & $\begin{array}{l}\text { D1: } \\
\text { ABEOKUTA }\end{array}$ & 194650 & 0.00 & \\
\hline S4: DUMMY & D2: ADO & 1466217 & 0.00 & 0.00 \\
\hline S4: DUMMY & D3: ILORIN & 2878598 & 0.00 & 0.00 \\
\hline S4: DUMMY & D4: OSOGBO & 2252565 & 0.00 & 0.00 \\
\hline S4: DUMMY & D6: SOKOTO & 765150 & 0.00 & 0.00 \\
\hline S4: DUMMY & D7: JOS & 486804 & 0.00 & 0.00 \\
\hline S4: DUMMY & D8: WARRI & 645788 & 0.00 & 0.00 \\
\hline S4: DUMMY & D9: BENIN & 1997399 & 0.00 & 0.00 \\
\hline S4: DUMMY & D10: OWERRI & 840473 & 0.00 & 0.00 \\
\hline S4: DUMMY & D11: ENUGU & 1024606 & 0.00 & 0.00 \\
\hline S4: DUMMY & $\begin{array}{l}\text { D12: } \\
\text { MARKUDI }\end{array}$ & 341292 & 0.00 & 0.00 \\
\hline
\end{tabular}

Table: 6

OBJECTIVE VALUE : 19,566,332.00

\section{Discussion}

The vogel's approximation method gives the total cost $(29,097,700: 00)$ that is close to the real optimal solution $(19,566,332.00)$ which is minimum cost of transportation

Also, the cost estimated through the north-west corner method $(36,689,050.00)$ is better than the one obtained through least cost method $(55,250,034.00)$.

The network diagram below shows all the routes that can be used in other to minimize the total cost of transportation.

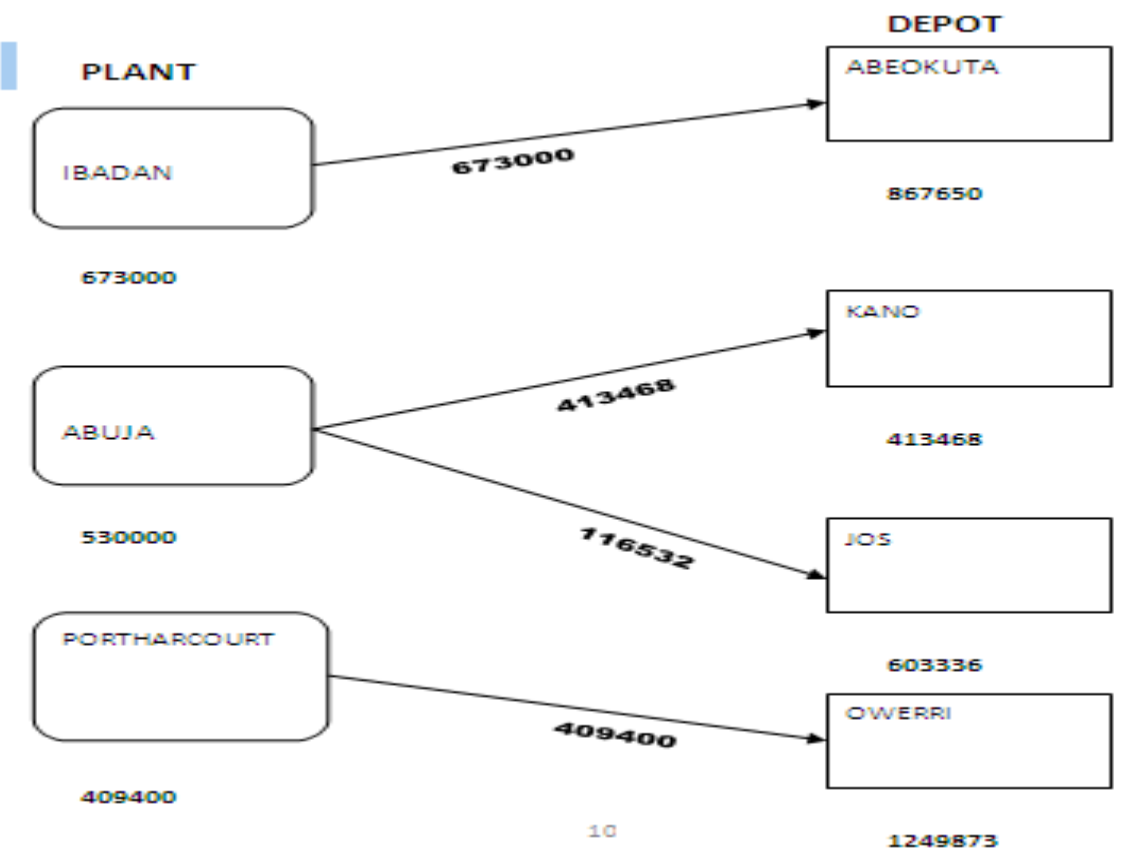

\section{Conclusion}

The data on the supply center capacity per year and the unit cost of transporting newspaper from each of the three (3) sources to twelve (12) destinations was analyzed in this research work, so as to obtain the optimum transportation cost and optimum transportation cost estimated is $\$ 19,566,332.00$. 
Also, Vogel's approximation method gave the value $(\mathrm{N29}, 097,700.00)$ that is closer to optimum solution. However, VAM is the best method out of suggested methods.

A dummy supply center with ten years capacity of $12,893,542$ is created to make transportation problem a balanced one.

Also, the study revealed that a production center should be created at northern part of the country (Nigeria) to replace the dummy supply center used in the analysis, so as to make production capacity equal to requirement.

\section{References}

[1]. Gass, SI (1990). On solving the transportation problem. Journal of Operational Research Society, 41(4), $291-297$.

[2]. Lucey T. (1981). Quantitative Techniques, Ashford Colour Press (Fifth edition), Great Britain.

[3]. Moskowlt, H. (1979). Operation Research Techniques for Management, Macmillian Publication C. In. (second edition), New York, U.S.A.

[4]. Oseni B. A and Ayansola O .A (2011). Quantitative Analysis Made Easy, Highland Publishers), Nigeria.

[5]. Prof. G. Srinivasan (2009). Fundamentals of Operations Research (A YouTube Video Tutorial). Department of Management Studies, IIT Madras.

[6]. Richard Bronson et al. (1997) Theory and Problems of Operation Research, Publisher: McGraw-

[7]. Hill USA.

[8]. Sharma J.K. (2009) Operation Research (Theory and Application) $4^{\text {th }}$ Edition, Macmillan

[9]. Publisher, Indian

[10]. Sudhakar V. J and Arunsankar .N (2012). A new approach for finding an Optimal Solution for Transportation Problem (Euro Journals Publishing) India pp. $254-257$

[11]. Taha H. A (2003). Operation Research - An Introduction, Prentice Hall of India ( $7^{\text {th }}$ Edition), India.

[12]. Wahab .A (2002). Basic Concept of Operation Research an Industrial Tool. Cobat Publication U.I, (Fifth Edition) Nigeria

[13]. Wikipedia Online Encyclopedia, (www. Wikipedia.com). 